\title{
Wastewater treatment processes for industrial organosilicon wastewater
}

\author{
Yongming $\mathrm{Wu}^{1}$, Mi Deng ${ }^{2}$, Lizhen $\mathrm{Liu}^{1}$, Jianyong $\mathrm{Wang}^{3}$, Jie Zhang ${ }^{1}$ and Jinbao Wan ${ }^{2}$ a \\ ${ }^{1}$ Poyang Lake Research Center, Jiangxi Academy of Sciences, Nanchang 330096, Jiangxi, China \\ ${ }^{2}$ Nanchang University, School of Resources Environmental \& Chemical Engineering, Nanchang 330031 \\ ${ }^{3}$ Jiangxi Hong Yi Environmental Engineering CO., LTD, Nanchang 330029
}

\begin{abstract}
One organosilicon company in Jiangxi province used the major processes including iron-carbon micro-electrolytic processes-Fenton-anaerobic-aerobic-coagulation $t$ reatment processes $\mathrm{t} o$ treat $\mathrm{t}$ he $\mathrm{w}$ astewater $\mathrm{f}$ rom or ganosilicon pr oduction. The $\mathrm{b}$ asis of technique selection, $t$ echnological processes, technological parameter a nd op eration ef fect $\mathrm{w}$ ere introduced. $T$ he $r$ esults $s$ howed $t$ hat, after $t$ hese $p$ rocesses, the $r$ emoval $r$ ates of chemical oxygen demand (COD), five-day biochemical oxygen demand ( $\mathrm{BOD}_{5}$, suspended solids ( $\mathrm{SS}$ ), and a mmonia ni trogen $\left(\mathrm{NH}_{3}-\mathrm{N}\right)$ were $304 \mathrm{~m} \mathrm{~g} / \mathrm{L}, 188 \mathrm{mg} / \mathrm{L}, 211 \mathrm{~m} \mathrm{~g} / \mathrm{L}$, a nd $36 \mathrm{~m} \mathrm{~g} / \mathrm{L}$, respectively. T he ef fluent $q$ uality $\mathrm{c}$ ould $\mathrm{r}$ each $\mathrm{t}$ he $\mathrm{t}$ hird gr ade i $\mathrm{n}$ Table $4 \mathrm{i} \mathrm{n}$ " Integrated Wastewater D ischarge Standard "(GB8978-1996), which could meet the requirement of the inflow water of local sewage treatment plant.
\end{abstract}

Keywords: organosilicon w astewater; f enton o xidation; i ron-carbon $\mathrm{m}$ icro-electrolysis; coagulating sedimentation.

\section{Introduction}

With $\mathrm{r}$ ising $\mathrm{l}$ iving $\mathrm{c}$ onditions, $\mathrm{t}$ he $\mathrm{d}$ emand o fo rganosilicon materials $\mathrm{s}$ uch a s $\mathrm{S}_{\mathrm{HCl}}$ increases $_{3}$ gradually[1]. In 10 years, the growth rate of demand for organic silicon monomer in our country had been kept in more than $20 \%$ [2], but in the meanwhile, the wastewater produced in the processes has the characteristics such as complicated composition, high chemical oxygen demand (COD), refractory compounds, extreme acidity, high toxicity and poor biochemical ability. If the wastewater drained off directly, it $\mathrm{c}$ ould $\mathrm{c}$ ause s erious $\mathrm{p}$ ollution in th e s urrounding water e nvironment. $\mathrm{T}$ herefore, it was important $t o$ treat ef fectively $t$ his kind of wastewater. P lenty o f $\mathrm{r}$ esearchers ap plied the $\mathrm{p}$ hysicchemical methods and biological methods such as photo-catalysis -oxidation technique[3], membrane treatment[4], F e-C micro e lectrolysis method[5,6], F enton ox idation[7-9], c ontact o xidation method[10], ozone method[11], and combined processes to treat organosilicon wastewater.

One o rganicsilicon e nterprise in $\mathrm{J}$ iangxi p rovince, i ncluded th e p roduction lin es o f $\mathrm{S} \mathrm{iHCl}_{3}$, organosilicon, ph enylhydrazine, $\mathrm{c}$ hloranil a nd ph enylhydrazine hy drochloride, the pr oduction 1 ine $\mathrm{SiHCl}_{3}$ among them produced the sewage including acid wastewater $\mathrm{HCl}$ and suspended solid of $\mathrm{SiO}_{2}$ [12]. According to the requirement of the environment ministry, to meet the influent quality of the local sewage treatment plant, the rail carbon micro-electrolytic processes-Fenton-anaerobic-aerobic-

${ }^{a}$ Corresponding author: jbwan@ncu.edu.cn 
coagulation treatment $\mathrm{p}$ rocesses were $\mathrm{u}$ sed to $\mathrm{t}$ reat $\mathrm{t}$ he wastewater $\mathrm{p}$ roduced in the o rganic silicon production, which make COD, five-day biochemical oxygen demand $\left(\mathrm{BOD}_{5}\right)$, suspended solids $(\mathrm{SS})$, and $\mathrm{NH}_{3}-\mathrm{N}$ in the final e ffluent meet the third grade in table 4 in "Integrated Wastewater Discharge Standard "(GB8978-1996), that is, the values of $\mathrm{pH}, \mathrm{COD}, \mathrm{BOD}_{5}, \mathrm{SS}$, and $\mathrm{NH}_{3}-\mathrm{N}$ were $6 \sim 9, \leq 500$ $\mathrm{mg} / \mathrm{L}, \leq 300 \mathrm{mg} / \mathrm{L}, \leq 400 \mathrm{mg} / \mathrm{L}$, and $\leq 50 \mathrm{mg} / \mathrm{L}$, respectively.

\section{Wastewater quality}

The $\mathrm{s}$ ewage from $\mathrm{t}$ he $\mathrm{p}$ roduction $\mathrm{l}$ ines of $\mathrm{SiHCl}_{3}$, o rganosilicon, $\mathrm{p}$ henylhydrazine, $\mathrm{c}$ hloranil a nd phenylhydrazine hy drochloride i n on e or ganicsilicon e nterprise i $\mathrm{n} J$ iangxi pr ovince i ncluded oi ly organic silicon, chloropropene, ethyl alcohol, aniline and inorganic salt and so on. Daily wastewater contained pr oducing wastewater ( high-concentration $\mathrm{w}$ aste $\mathrm{w}$ ater) and $\mathrm{n}$ on-producing $\mathrm{w}$ astewater (low-concentration waste water). Among them, $\mathrm{COD}, \mathrm{BOD}_{5}$, aniline, $\mathrm{SS}, \mathrm{pH}, \mathrm{NH}_{3}-\mathrm{N}$, and water flow in high-concentration waste water were $10000 \sim 20000 \mathrm{mg} / \mathrm{L}, 600 \sim 800 \mathrm{mg} / \mathrm{L}, 18 \mathrm{mg} / \mathrm{L}, 900 \mathrm{mg} / \mathrm{L}, 4 \sim 6$, $100 \mathrm{~m} \mathrm{~g} / \mathrm{L}$, a nd $40 \mathrm{~m}^{3} / \mathrm{d}, \mathrm{r}$ espectively. W hereas there were $\mathrm{m}$ ainly washing water an $\mathrm{d}$ h ousehold wastewater in low-concentration wastewater, the main pollutants mainly included acid base and SS, and the water flow was $80 \mathrm{~m}^{3} / \mathrm{d}$. The water quality and quantity of these two kinds of wastewater were shown in Table 1.

Table 1 . The water quality of wastewater

\begin{tabular}{|c|c|c|c|c|c|c|}
\hline Water quality & $\begin{array}{c}\text { Water flow } \\
\left.\mathbf{( m}^{\mathbf{3}} / \mathbf{d}\right)\end{array}$ & $\begin{array}{c}\mathbf{C O D}_{\mathbf{C r}} \\
\mathbf{( m g / L )}\end{array}$ & $\begin{array}{c}\mathbf{B O D}_{\mathbf{5}} \\
\mathbf{( \mathbf { m g } / \mathbf { L } )}\end{array}$ & $\begin{array}{c}\mathbf{S S} \\
\mathbf{( m g / L )}\end{array}$ & $\begin{array}{c}\mathbf{N H}_{3}-\mathbf{N} \\
\mathbf{( m g / L )}\end{array}$ & $\mathbf{p H}$ \\
\hline $\begin{array}{c}\text { high- } \\
\text { concentration } \\
\text { waste water }\end{array}$ & 40 & 15000 & 700 & 900 & 100 & $4 \sim 6$ \\
\hline $\begin{array}{c}\text { Low- } \\
\text { concentration } \\
\text { waste water }\end{array}$ & 80 & 600 & 100 & 1000 & 45 & $4 \sim 7$ \\
\hline
\end{tabular}

\section{Process of wastewater treatment and descriptions}

\subsection{The process of wastewater treatment}

According to the influent load and water quality, and the best optimizing process based on the results from in-situ survey a nd experiments in lab-scale and in pilot-scale, the co mbined p rocesses of $\mathrm{r}$ ail carbon micro-electrolytic processes-Fenton-anaerobic-aerobic-coagulation treatment were confirmed. The designed water flow in the wastewater treatment station was $120 \mathrm{~m}^{3} / \mathrm{d}$, and the treatment process was shown in Figure 1. 


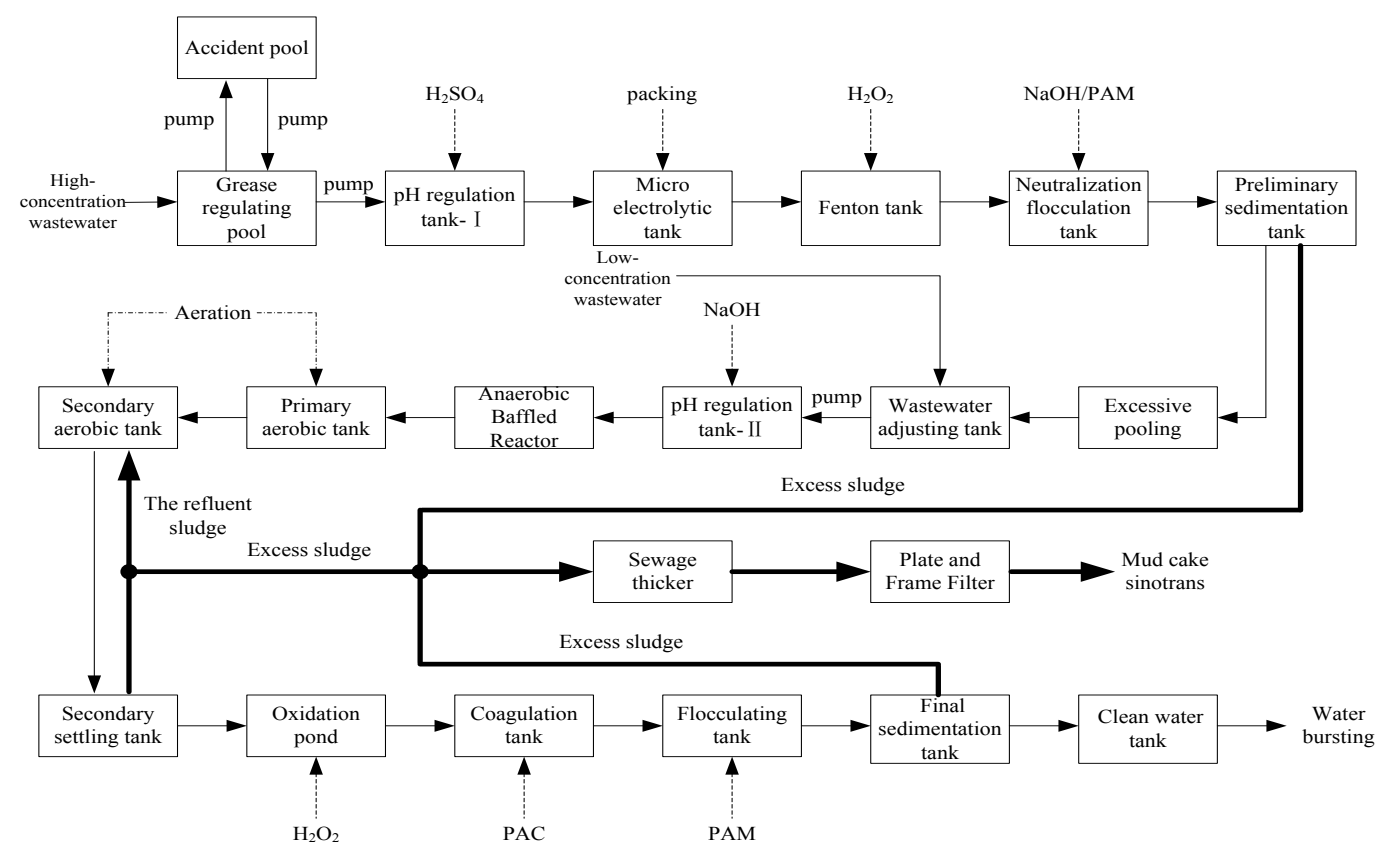

Figure 1. The process flow diagram of wastewater treatment

As s hown i $\mathrm{n} \mathrm{F}$ ig. 1 , $\mathrm{t}$ he $\mathrm{h}$ igh-concentration a nd $\mathrm{l}$ ow-concentration wastewater i $\mathrm{n} t$ he en tire treatment p rocesses were s eparately treated. For high-concentration w astewater, it was first entered into the grease regulation pool, and then into $\mathrm{pH}$ regulation tank I to regulate $\mathrm{pH}$ value by the lifting pump, followed by the effluent enter into advanced oxidation pretreatment reactor which including the iron-carbon filter, $\mathrm{H}_{2} \mathrm{O}_{2}, \mathrm{NaOH}$ and poly acrylamide (PAM) for sectional treatment, then the effluents were i nitially $\mathrm{p}$ recipitated. A fter mixture in E xcessive $\mathrm{p}$ ooling, the e ffluent a nd lo w-concentration wastewater were together flowed into comprehensive regulation pool, and the effluents were run into $\mathrm{pH}$ regulation tank II by lifting pump and the $\mathrm{pH}$ value were adjusted by $\mathrm{NaOH}$ to be neutual to keep the an aerobic $t$ reatment e ffect of ABR. $\mathrm{T}$ he $\mathrm{B} / \mathrm{C} \mathrm{r}$ atio $\mathrm{v}$ alue of wastewater was el evated b y $\mathrm{t}$ he $\mathrm{ABR}$ (Anaerobic Baffled Reactor) process, the effluents flow into first and Secondary aerobic tank in turn to further reduce $\mathrm{COD}$ and $\mathrm{NH}_{3}-\mathrm{N}$. A fter treatment by the s econdary s edimentation tank, the supernatants flow into the ad vanced treatment reator which included $\mathrm{H}_{2} \mathrm{O}_{2}$, polyaluminium chloride (PAC) and PAM (the dosage of PAC and PAM et al. was depended on effluent quality). The effluents were co ntrolled to r each the third grade in Table 4 in "Integrated W astewater D ischarge S tandard "(GB8978-1996), an $\mathrm{d} w$ ere $d$ ischarged i nto the $s$ ewage $t$ reatment $p$ lant $t$ hrough $t$ he $s$ ewage $p$ ipe network for further treatment. The s ewages from the p rimary, s econd, an $d$ f inal s etting tank were discharged into sludge thickening tank, and then were dehydrated by the plate-and-frame filter press. The mud cakes were tranported to treat safely.

\subsection{Main structures of wastewater treatment}

\subsubsection{Regulation pool of high-concentration wastewater}

One regulation pool was designed by the inflow of $2 \mathrm{~m}^{3} / \mathrm{h}$, which was within grease trap to store highconcentration wastewater from the plant, and meanwhile to homogenize the water quality and quantity in o rder $\mathrm{t} o \mathrm{k}$ eep $\mathrm{t}$ he subsequet $\mathrm{t}$ reatment $\mathrm{f}$ acilities operate $\mathrm{o}$ rderly. $\mathrm{T}$ he $\mathrm{s}$ ize o $\mathrm{f}$ design was $4.00 \times 5.00 \times 5.00 \mathrm{~m}$, with the effective height of $4.00 \mathrm{~m}$, the effective volumn of $80 \mathrm{~m}^{3}$, and hydraulic retention time (HRT) of $40 \mathrm{~h}$. The underground steel concrete structure and the preservative treatment was applied. 


\subsection{2 $\mathrm{pH}$ regulation tank I}

Two pools were designed by the inflow of $2 \mathrm{~m}^{3} / \mathrm{h}$. The $\mathrm{pH}$ values of the influents in these pools were adjusted by $\mathrm{NaOH}$, in order to meet the conditions of micro-electrolytic reaction. The size of design is $0.90 \times 1.00 \times 3.00 \mathrm{~m}$, with the effective height of $2.5 \mathrm{~m}$, the effective volumn $5.4 \mathrm{~m}^{3}$, and the HRT of $2.7 \mathrm{~h}$. The half-ground steel conctete structure and the preservative treatment was applied.

\subsubsection{Micro-electrolytic tank}

One tank, designed by the inflow of $2 \mathrm{~m}^{3} / \mathrm{h}$, was used to pretreat high-concentration wastewater, and was applied to have electrical-chemical reaction by iron scurf and carbon granule. In weak electric field, the ch arged co lloidal $\mathrm{p}$ articles were $\mathrm{u}$ nstable to ag gregate to $\mathrm{p}$ recipitate. $\mathrm{T}$ he $\mathrm{B} / \mathrm{C} \mathrm{v}$ alues in wastewater were improved, and then the biodegradability of wastewater was elevated. The designed size is $2.00 \times 2.00 \times 5.00 \mathrm{~m}$, with the effective height of $4.5 \mathrm{~m}$, the effective volumn of $19 \mathrm{~m}^{3}$, and HRT of $9 \mathrm{~h}$. The half-ground steel conctete structure and the preservative treatment was applied.

\subsubsection{Fenton tank}

Two $t$ anks were de signed by the i nflow of $2 \mathrm{~m}^{3} / \mathrm{h} . \mathrm{H}_{2} \mathrm{O}_{2}$ and $\mathrm{F} \mathrm{e}^{2+}$ were ad ded an $\mathrm{d} t$ heir $\mathrm{s}$ trong oxidizability was used for chemical oxidation pretreatment. Its design size is $0.90 \times 1.00 \times 3.00 \mathrm{~m}$, with the effective height of $2.5 \mathrm{~m}$, the effective volumn of $5.4 \mathrm{~m}^{3}$, and HRT of $2.7 \mathrm{~h}$. The half-ground steel conctete structure and the preservative treatment was applied.

\subsubsection{Neutralization and flocculation tank}

Two tanks were de signed by the inflow of $2 \mathrm{~m}^{3} / \mathrm{h}$. NaOH was ad ded to regulate the $\mathrm{pH}$ values in orginal water to meet the necessary range of $\mathrm{pH}$ values in the subsequet biochemical treatment. The design size is $0.90 \times 1.00 \times 3.00 \mathrm{~m}$, with the effective height of $2.5 \mathrm{~m}$, the effective volumn of $5.4 \mathrm{~m}^{3}$, and HRT of $2.7 \mathrm{~h}$. The half-ground steel conctete structure and the preservative treatment was applied.

\subsubsection{Preliminary sedimentation tank}

One tank, designed by the inflow of $2 \mathrm{~m}^{3} / \mathrm{h}$, was used to hydraulically clarify the wastewater after pretreatment, and to decrease the treatment load, and to benefit the subsequent treated processes. The design size is $2.00 \times 3.60 \times 5.00 \mathrm{~m}$, with the effective height of $4.5 \mathrm{~m}$, the effective volumn of $32.4 \mathrm{~m}^{3}$, and the hydraulic surface loading of $0.28 \mathrm{~m}^{3} / \mathrm{m}^{2} \cdot \mathrm{h}$. The half-ground steel conctete structure and the preservative treatment was applied.

\subsubsection{Wastewater adjusting tank}

One $\mathrm{t}$ ank was d esigned b y the i nflow of $6.0 \mathrm{~m}^{3} / \mathrm{h}$, which was within grease $\mathrm{trap} \mathrm{t}$ o s tore hi ghconcentration and low- concentration wastewater after pretreatment, and meanwhile to homogenize the water quality and quantity in order to keep the subsequet treatment facilities operate orderly. The size of design was $4.00 \times 7.40 \times 5.00 \mathrm{~m}$, with the effective height of $4.00 \mathrm{~m}$, the effective volumn of $118.4 \mathrm{~m}^{3}$, and HRT of $19.7 \mathrm{~h}$. The underground steel concrete structure and the preservative treatment was applied.

\subsection{8 $\mathrm{pH}$ regulation tank II}

Two tanks were designed by the inflow of $6.0 \mathrm{~m}^{3} / \mathrm{h}$. NaOH was added to regulate the $\mathrm{pH}$ values in orginal water to meet the necessary range of $\mathrm{pH}$ values in the subsequet biochemical treatment. The 
design size is $0.90 \times 2.00 \times 3.00 \mathrm{~m}$, with the effective height of $2.5 \mathrm{~m}$, the effective volumn of $9.0 \mathrm{~m}^{3}$, and HRT of $1.5 \mathrm{~h}$. The half-ground steel conctete structure and the preservative treatment was applied.

\subsubsection{Anaerobic baffled reactor}

One tank, designed by the inflow of $6.0 \mathrm{~m}^{3} / \mathrm{h}$, was used to have anaerobic chemistry to treat highconcentration wastewater, $\mathrm{t}$ o d ecrease $\mathrm{t}$ he $\mathrm{s}$ ubsequent treatment $\mathrm{l} \mathrm{oad}$, an $\mathrm{d} t$ hen to $\mathrm{i}$ mprove $\mathrm{t}$ he biodegradability of wastewater, which would benefit the subsequent aerobic treatment. The designed size is $16.60 \times 4.00 \times 5.00 \mathrm{~m}$, with the effective height of $4.5 \mathrm{~m}$, the effective volumn of $298.8 \mathrm{~m}^{3}$, and HRT of $49.8 \mathrm{~h}$. The half-ground steel conctete structure was applied.

\subsubsection{Primary aerobic tank}

One $t$ ank, $d$ esigned b y t he the i nflow of $6.0 \mathrm{~m}^{3} / \mathrm{h}$, was u sed $\mathrm{t}$ o $\mathrm{r}$ emove $\mathrm{t}$ he o rganic matters i $\mathrm{n}$ wastewater $\mathrm{b}$ y microbial $\mathrm{b}$ iochemical e ffect $\mathrm{b}$ ased $\mathrm{o} \mathrm{n}$ considering $\mathrm{s}$ ome mixed $\mathrm{b}$ ackflow. $\mathrm{T}$ he designed size is $16.60 \times 4.00 \times 5.00 \mathrm{~m}$, with the effective height of $4.5 \mathrm{~m}$, the effective volumn of 298.8 $\mathrm{m}^{3}$, and HRT of $49.8 \mathrm{~h}$. The half-ground steel conctete structure was applied.

\subsubsection{Secondary aerobic tank (including second sedimentation tank)}

One tank was designed by the the inflow of $6.0 \mathrm{~m}^{3} / \mathrm{h}$. The biofilters were added, and the microbial biochemical ef fect o $\mathrm{n} t$ he surface of stuffings was used $\mathrm{t}$ o $\mathrm{r}$ emove o rganic matters $\mathrm{b}$ ased o $\mathrm{n}$ considering s ime mixed $\mathrm{b}$ ackflow. On the o ther $\mathrm{h}$ and, the wastewater af ter aer obic treatment was hydraulically clarified through s econ s edimentation tank. The de signed size is $16.60 \times 4.10 \times 5.00 \mathrm{~m}$, with the effective height of $4.5 \mathrm{~m}$, the e ffective volumn of $39.0 \mathrm{~m}^{3}$, and HRT of $1.5 \mathrm{~h}$. The halfground steel conctete structure was applied.

\subsubsection{Oxidation pond}

One tank was designed by the the inflow of $6.0 \mathrm{~m}^{3} / \mathrm{h} . \mathrm{H}_{2} \mathrm{O}_{2}$ was added into this tank to have final treatment of chemical oxidation. The designed size is $2.00 \times 1.00 \times 5.00 \mathrm{~m}$, with the effective height of $4.50 \mathrm{~m}$, the effective volumn of $39.0 \mathrm{~m}^{3}$, and HRT of $1.5 \mathrm{~h}$. The half-ground steel conctete structure was applied.

\subsubsection{Coagulation tank}

One tank was de signed by the the inflow of $6.0 \mathrm{~m}^{3} / \mathrm{h}$. P AC was ad ded, an $\mathrm{d}$ h as the ef fect of the compression of double charge, charge neutralization and adsorption bridge and net and so on, which make the small suspended particles and gel ions to aggregate, floccuate, coagulate, sedimentate, and then $\mathrm{r}$ each the ef fect of $\mathrm{p}$ urification treatment ${ }^{[13]}$. The de sign s ize is $2.00 \times 1.00 \times 3.00 \mathrm{~m}$, with the effective height of $2.5 \mathrm{~m}$, the ef fective volumn of $5 \mathrm{~m}^{3}$, and H RT of $1.5 \mathrm{~h}$. The half-ground s teel conctete structure was applied.

\subsubsection{Flocculation tank}

One tank was designed by the the inflow of $6.0 \mathrm{~m}^{3} / \mathrm{h}$. PAM[14] was added and the high hydrophilic ionic groups such as amido on the molecular chain of PAM was used to realize the absorption of small molecule suspended s ubstances i n wastewaters. T he d esign size is $2.00 \times 1.00 \times 3.00 \mathrm{~m}$, with the effective height of $2.5 \mathrm{~m}$, the e ffective volumn of $5 \mathrm{~m}^{3}$, and H RT of $1.5 \mathrm{~h}$. The half-ground s teel conctete structure was applied. 


\subsubsection{Final sedimentation tank}

One $\mathrm{t}$ ank was de signed b y t he $\mathrm{t}$ he i nflow of $6.0 \mathrm{~m}^{3} / \mathrm{h}$. I t m ainly cl arify t he wastewater a fter coagulation and flocculation. The design size is $2.00 \times 5.00 \times 5.00 \mathrm{~m}$, with the effective height of $4.5 \mathrm{~m}$, the effective volumn of $45 \mathrm{~m}^{3}$, and the hydraulic surface loading of $0.6 \mathrm{~m}^{3} / \mathrm{m}^{2} \cdot \mathrm{h}$. The half-ground steel conctete structure was applied.

\section{The running condition of the debugging process}

After c ompletion o f s ystem de bugging i n ope ration, a nd t he c ontinue s ampling t est b y 1 ocal environmental monitoring station, the results showed that, the concentrations of $\mathrm{COD}, \mathrm{BOD}_{5}, \mathrm{SS}$, and $\mathrm{NH}_{3}-\mathrm{N}$ of the final effluents were $304 \mathrm{mg} / \mathrm{L}, 188 \mathrm{mg}, 211 \mathrm{mg} / \mathrm{L}$, and $36 \mathrm{mg} / \mathrm{L}$, respectively. They were apparently better than the third grade in Table 4 in "Integrated Wastewater Discharge Standard "(GB8978-1996), and reached the requirement of influent quality of local sewage treatment plant. The monitoring data of part effluent quality were shown in Table 2.

Table 2. The main structures of treatments

\begin{tabular}{|c|c|c|c|c|c|}
\hline \multirow{2}{*}{\multicolumn{2}{|c|}{ Treatment units }} & \multicolumn{4}{|c|}{ Parameter } \\
\hline & & COD & BOD $_{5}$ & SS & $\mathbf{N H}_{3}-\mathbf{N}$ \\
\hline \multirow{3}{*}{ Regulation pool } & Influent(mg/L) & 15000 & 700 & 900 & 100 \\
\hline & Removal rates $/ \%$ & l & l & 10 & l \\
\hline & effluent(mg/L) & 15000 & 700 & 800 & 100 \\
\hline \multirow{2}{*}{$\begin{array}{l}\text { micro-electrolytic } \\
\text { pool/Feton po ol } \\
\text { /neutralized } \\
\text { flocculation p ool } \\
\text { /primary s etting } \\
\text { tank }\end{array}$} & Removal rates $/ \%$ & 75 & 25 & 30 & 10 \\
\hline & effluent(mg/L) & 3750 & 525 & 560 & 90 \\
\hline \multirow{2}{*}{$\mathrm{ABR}$} & Removal rates $/ \%$ & 60 & 15 & 10 & 5 \\
\hline & Efflent(mg/L) & 1500 & 446 & 504 & 85 \\
\hline \multirow{2}{*}{$\begin{array}{l}\text { Primary aer obic } \\
\text { tank / S econdary } \\
\text { aerobic tank }\end{array}$} & Removal rate $/ \%$ & 55 & 40 & 20 & 35 \\
\hline & effluent(mg/L) & 675 & 268 & 403 & 55 \\
\hline \multirow{2}{*}{$\begin{array}{l}\text { Secondary } \\
\text { sedimentation } \\
\text { tank }\end{array}$} & Removal rate/\% & l & / & 25 & l \\
\hline & effluent(mg/L) & 675 & 268 & 302 & 55 \\
\hline \multirow{2}{*}{$\begin{array}{l}\text { Oxidation po nd / } \\
\text { Coagulating ba sin } \\
\text { / F locculation } \\
\text { basin / Final } \\
\text { setting tank }\end{array}$} & Removal rate $/ \%$ & 55 & 30 & 30 & 35 \\
\hline & effluent(mg/L) & 304 & 188 & 211 & 36 \\
\hline \multicolumn{2}{|l|}{ Total remoal rate $\%$} & 98.0 & 73.1 & 76.6 & 64.0 \\
\hline \multicolumn{2}{|c|}{ Discharged requirements } & 500 & 300 & 400 & 50 \\
\hline
\end{tabular}

\section{Technical and economic analysis}

The main cost of this project contained electric charge and medicament expense. According to the statistics, if the electric charge was calculated by 0.8 yuan per kilowatt hour, then 253.2 yuan per day woud be paid for electric charge. That is, to treat one ton wastewater would cost 2.11 Yuan of electric 
charge. The medicament expense including $\mathrm{NaOH}, \mathrm{PAC}, \mathrm{PAM}$, and $\mathrm{H}_{2} \mathrm{O}_{2}$, the corresponding prices of them were 4000 yuan/ton, 2200 yuan/ton, 24000 yuan/ton, and 1200 yuan/ton. One ton wastewater would c onsume 0.48 y uan $\mathrm{N} \mathrm{aOH}, 0.22$ y uan $\mathrm{P} \mathrm{AC,} 0.12$ y uan $\mathrm{P} A M$, a nd 0.06 y uan $\mathrm{H}_{2} \mathrm{O}_{2}$. T he medicament expense used to treat one ton wastewater was 0.88 yuan. The total operational cost of per ton wastewater treatment would be 2.99 yuan.

\section{Conclusion}

For the sewage from the production lines of $\mathrm{SiHCl}_{3}$, organosilicon, phenylhydrazine, chloranil and phenylhydrazine hy drochloride, the $\mathrm{m}$ ain processes of rail-carbon $\mathrm{m}$ icro-electrolytic processesFenton-anaerobic- aerobic-coagulation treatment were applied. The concentrations of $\mathrm{COD}, \mathrm{BOD}_{5}, \mathrm{SS}$, and $\mathrm{NH}_{3}-\mathrm{N}$ of the final effluents were $304 \mathrm{mg} / \mathrm{L}, 188 \mathrm{mg}, 211 \mathrm{mg} / \mathrm{L}$, and $36 \mathrm{mg} / \mathrm{L}$, respectively, which were ap parently better than the third grade standard of "Integrated Wastewater Discharge Standard (GB8978-1996) ", and reached the requirement of influent quality of local sewage treatment plant. The operating cost without labor cost only contains electric charge and medicament expense, and the total cost was 2.99 yuan/ton wastewater.

\section{References}

1. X.X. Sun, H.X. Guo, Y.H. Liang, et al. Application progress of silicone compound[J]. Chem. Product. Tech. (in Chinese), 14:51-54 (2007).

2. F.J. Li. Study on the integrated treatment of organic silicon wastewater[J]. Clean. World (in chinese), 26:24-26 (2010).

3. W.C. Tan, J.H. Li, J.L. Wan, et al. Pretreatment of wastewater from silicone resin production by photocatalytic oxidation process[J]. Indust. Wat. Treat. (in chinese), 32:87-89 (2012).

4. Q.D. Lei, Z. Shen, Y.X. Zhao. Treatment of organosilicon production wastewater and control of membrane fouling[J]. Environ. Protec. Chem. Indust. (in chinese), 32:247-250 (2012).

5. W.G. Tong, R.W. Mei, Y.F. Wei. Research process of comprehensive treatment of organosilicon production wastewater[J]. Wat. Wastewa. Eng. (in chinese), 37:145-148 (2011).

6. G.S. Zhang, J.H. Qu, H.J. Liu, et al. Magnetic adsobents: activated carbon/iron oxide composites for $\mathrm{AO}_{7}$ removal from aqueous system[J]. Acta Sci. Circum., 26:1763-1768 (2006).

7. W.B. Wang, W.C. Tan, S.X. Zheng, et al. Two-stage oxidation of wastewater containing organic silicon by Fenton reagent[J]. Chinese J. Environ. Eng. (in chinese), 4:776-780 (2010).

8. S.U. Yuan, M. Tian, Y.P.Cui, et al. Treatment of nitrophenols by cathode reduction and electrofenton methods [J].J. Haz. Mat., 137:573-580 (2006).

9. A. Ventura, G. Jacquet, A. Bermond, et al. Electrochemical generation of the Fenton's reagent: application to atrazine degradation[J].Wat. Res., 36:3517-3522 (2002).

10. L.T. Pan, J.F. Wu, J. Wang, et al. Treatment of organosilicon wastewater by iron-carbon microelectrolysis-hydrolysis acidification-biological contact oxidation process[J]. Chinese J. Environ. Eng. (in chinese), 4:595-598 (2010).

11. C.S. Ding, J. Miao, S.L. Qin, et al. Influencing factors of high-concentration organic wastewater treatment by $\mathrm{O}_{3}-\mathrm{UV}$ using granular activated carbon (GAC) as the catalyst[J]. Acta Sci. Circum. (in chinese), 28:496-501 (2008).

12. F.C. Zeng. Treatment of tail gas washing wastewater from $\mathrm{SIHCl} 3$ production by neutralizationcoagulation process[J]. Indust. Wat.Treat., 31:67-69 (2011).

13. F.M. Lin, W.Z. Lin, X.H. Li, et al. UASB-activated sludge-contact oxidation-coagulation sedimentation process to treat chemical production wastewater[J]. Wat. Wastewat. Eng. (in chinese), 37:50-53 (2011).

14. Y.M. Tang, B.H. Guan, Z.B. Wu. Fenton oxidation- PAM flocculation-A/O process to treat Methyldopa production wastewater. Wat. Wastewat. Eng. (in chinese), 32: 49-51(2006). 